\title{
Analyzing a self-managed CHP system for greenhouse cultivation as a profitable way to reduce $\mathrm{CO}_{2}$-emissions
}

\author{
Tine Compernolle*, Nele Witters, Steven Van Passel, Theo Thewys
}

Hasselt University, Centre for Environmental Science, 3590 Diepenbeek, Belgium

\section{A R T I C L E I N F O}

\section{Article history:}

Received 10 September 2009

Received in revised form

4 February 2010

Accepted 26 February 2010

Available online 2 April 2010

\section{Keywords:}

Combined Heat and Power (CHP)

Net Present Value

Monte Carlo

$\mathrm{CO}_{2}$ emission reduction

\begin{abstract}
A B S T R A C T
To counter global warming, a transition to a low-carbon economy is needed. The greenhouse sector can contribute by installing Combined Heat and Power (CHP) systems, known for their excellent energy efficiency. Due to the recent European liberalization of the energy market, glass horticulturists have the opportunity to sell excess electricity to the market and by tailored policy and support measures, regional governments can fill the lack of technical and economic knowledge, causing initial resistance. This research investigates the economic and environmental opportunities using two detailed cases applying a self managed cogeneration system. The Net Present Value is calculated to investigate the economic feasibility. The Primary Energy Saving, the $\mathrm{CO}_{2}$ Emission Reduction indicator and an Emission Balance are applied to quantify the environmental impact. The results demonstrate that a self-managed CHP system is economic viable and that $\mathrm{CO}_{2}$ emissions are reduced.
\end{abstract}

(c) 2010 Elsevier Ltd. All rights reserved.

\section{Introduction and problem statement}

The Intergovernmental Panel on Climate Change (IPCC) states in its fourth assessment report that the warming of the climate system is unequivocal. On the other hand, there is agreement and much evidence that stabilization levels can be achieved by using a portfolio of existing technologies and technologies expected to be commercialized in coming decades [1]. A transition to a low carbon economy is needed and although clear challenges and costs to our economy have to be faced, it also presents opportunities. Markets for low-carbon and high efficiency goods are set for a prolonged period of rapid growth [2].

The foundation of global efforts to battle global warming was already formed in 1992 by signing the UN Framework Convention on Climate Change at the Rio Earth Summit. An important step within this framework is the Kyoto Protocol, adopted in Kyoto in 1997. This international agreement commits the industrialized countries to reduce their overall emissions of greenhouse gases by at least 5\% below 1990 levels in the period 2008-2012 [3]. At that time, the European Union committed herself to reduce greenhouse gas emissions by $8 \%$ and now she goes even further. In 2008, the EU proposed an integrated energy and climate change policy, including the following objectives: by 2020, the emissions of greenhouse gasses has to be cut by $20 \%, 20 \%$ of total energy has to be produced by using

\footnotetext{
* Corresponding author. Tel: +32 112687 48; fax: +32 11268799

E-mail address: tine.compernolle@uhasselt.be (T. Compernolle).
}

renewable resources and also the energy consumption has to decrease by $20 \%$ [4]. A wide range of clean technologies can contribute towards the sustainable production of energy. Common examples are wind, solar and biomass. Also cogeneration or combined heat and power (CHP) can be seen as an important technology to reduce carbon emissions resulting from energy production $[5,6]$.

From the dairy industry [7] to the sugar industry [8] and pasta factories [9]: the potential of CHP development is present in many industries. This research will focus on the possibilities of CHP in the greenhouse sector, the most energy consuming sector within agriculture. CHP - systems are already used in several greenhouse complexes, especially in the Netherlands. According to Critten et al. [10], the exploitation of CHP - systems can serve energy conservation objectives because the produced heat can be fully used, which is not the case at large power plants. Canova et al. [11] refer to cogeneration as a system widely known for its excellent efficiency concerning fuel consumption compared to the separate production of the same amount of heat and electricity.

A common CHP system can be described as an installation consisting of an internal combustion engine or a gas turbine that drives an electric generator. Horticulturists mostly draw up partnerships with power companies that own the units [10,12]. Within these partnerships, the growers obtain the heat - reclaimed from the engine - at a discount rate and some electricity. The excess electricity is sold by the power company to the national grid network. These partnerships however, have the disadvantage of the growers being dependent on the operating policy of the power plant. Growers prefer not to exploit the CHP system themselves 


\begin{tabular}{|c|c|c|c|}
\hline \multicolumn{2}{|c|}{ Nomenclature } & $\eta_{\mathrm{Q}}^{\mathrm{SP}}$ & reference efficiency boiler \\
\hline $\mathrm{CHP}$ & Combined Heat and Power & $\eta_{\mathrm{E}}^{\mathrm{SP}}$ & reference efficiency power plant \\
\hline$b$ & tax rate & $E_{\mathrm{gh}}$ & electricity used in the greenhouse $\left(\mathrm{MWh}_{\mathrm{e}}\right)$ \\
\hline EHO & Extra Heavy Oil & $Q^{\mathrm{Y}}$ & cogenerated heat $\left(\mathrm{MWh}_{\mathrm{th}}\right)=Q_{\text {condenser }}+Q_{\mathrm{cc}}$ \\
\hline$I_{0}$ & capital cost & $Q_{\text {cond. }}$ & heat recovered by the condenser $\left(\mathrm{MWh}_{\mathrm{th}}\right)$ \\
\hline SP & separate production & $Q_{c c}$ & heat recovered by the cooling circuit of the CHP system \\
\hline$A_{t}$ & depreciation amount in year $t$ & & $\left(\mathrm{MWh}_{\mathrm{th}}\right)$ \\
\hline NPV & Net Present Value & $Q_{b}$ & heat produced by an auxiliary boiler $\left(\mathrm{MWh}_{\mathrm{th}}\right)$ \\
\hline$i$ & actual interest rate after taxes & $\mathrm{CO}_{2} \mathrm{ER}$ & $\mathrm{CO}_{2}$ Emission Reduction indicator \\
\hline IRR & internal rate of return & $\Delta m_{X}$ & mass difference of emitted pollutant $X$ \\
\hline$O_{t}$ & incoming cash flow in year $t$ & $m_{X}^{Y}$ & mass of pollutant $X$ emitted by CHP \\
\hline PES & Primary Energy Saving & $m_{X}^{\mathrm{SP}}$ & mass of pollutant $X$ emitted by the SP of $E^{\mathrm{Y}}$ and $Q^{\mathrm{Y}}$ \\
\hline$Q_{t}$ & outgoing cash flow in year $t$ & & (Sum of $m_{X E}^{\mathrm{SP}}$ and $m_{X Q}^{\mathrm{SP}}$ ) \\
\hline$F^{Y}$ & fuel input of the CHP system & $m_{\mathrm{XE}}^{\mathrm{SP}}$ & mass of pollutant $X$ emitted by the SP of $E^{\mathrm{Y}}$ \\
\hline$n$ & expected lifetime of the project & $\mathrm{m}_{\mathrm{XQ}}^{\mathrm{SP}}$ & mass of pollutant $X$ emitted by the SP of $Q^{Y}$ \\
\hline$F^{\mathrm{SP}}$ & fuel input of the SP of $E^{Y}$ and $Q^{Y}$ & $\mu_{\mathrm{XE}}^{\mathrm{Y}}$ & electric output related emission factor of pollutant $X$ \\
\hline$F^{\mathrm{B}}$ & fuel input auxiliary boiler & & for the CHP system \\
\hline$\eta_{\mathrm{Q}}^{\mathrm{Y}}$ & thermal efficiency CHP system & $\mu_{\mathrm{XE}}^{\mathrm{SP}}$ & output related emission factor of pollutant $X$ for the \\
\hline$E^{Y}$ & cogenerated electricity $\left(\mathrm{MWh}_{\mathrm{e}}\right)$ & & separate production of $E^{\mathrm{Y}}$ \\
\hline$\eta_{\mathrm{E}}^{\mathrm{Y}}$ & electric efficiency CHP system & $\mu_{\mathrm{XQ}}^{\mathrm{SP}}$ & output related emission factor of pollutant $X$ for the \\
\hline$E_{\mathrm{s}}$ & electricity sold $\left(\mathrm{MWh}_{\mathrm{e}}\right)$ & & separate production of $Q^{Y}$ \\
\hline
\end{tabular}

because of the high capital cost and the imbalance between heat and electricity consumption. Excess produced electricity cannot be used by the horticulturists [10]. However, across the European Union, a competitive internal market for electricity and gas has been progressively implemented since 2000. In recent years, the liberalization of the energy market gives horticulturists the opportunity to sell the generated surplus electricity freely to the market. Moreover, national governments established certificate markets: when producing electricity using qualitative CHP systems, growers will receive certificates which can be sold to electricity plants that need to fulfill a certificate duty. European governments can also stimulate the placement of CHP systems by granting subsidies or an investment allowance.

The commitments made on global and local scale and the energy market liberalization give reason to investigate whether the exploitation of a CHP system by glass horticulturists is achievable. This research paper will investigate the feasibility of CHP in horticulture by using two case studies of a self - managed gas fuelled cogeneration system. The research focus will lie on the economic viability (starting from the technical feasibility) and on the impact of the exploitation of a CHP-system on the environment. One case study investigates tomatoes with a high heat demand and a low need for electricity, while the other case study examines lettuce, cultivated by use of assimilation lighting with a lower heat and a higher electricity demand.

\section{Methodology}

This section will give an overview of the methods used to examine whether investing in a CHP system is economically achievable and what the impact is on energy use and air quality. The Net Present Value (NPV) approach is applied to investigate the economically feasibility. To verify whether a CHP system is fuel saving, the Primary Energy Saving (PES) is calculated. The impact on air quality is determined by applying the $\mathrm{CO}_{2}$ Emission Reduction $\left(\mathrm{CO}_{2} \mathrm{ER}\right)$ indicator and by setting up a Local and Global Emission Balance. Before the NPV can be calculated, the capacity of the CHP system was determined. Considering the fact that this research focuses on the economic and environmental aspects of $\mathrm{CHP}$, the dimensioning of the CHP system is only explained briefly in the last paragraph of this section.

\subsection{Economic feasibility: Net Present Value (NPV)}

Frequently, the Payback Time, the Internal Rate of Return and the Net Present Value are applied to verify whether or not investing in a CHP system is worthwhile financially [13-16]. Table 1 gives an overview of the results of previous case studies.

The Payback Time is determined as the time needed to pay back the initial investment with the incoming cash flows. Although this method has the advantage of being generally known and easy to apply, it doesn't take the time value of money into account. Moreover, when applying the payback time, no information is obtained about the profit generated from the investment during the further lifetime of the project, i.e. after the investment has been paid back. The NPV is calculated by subtracting the investment cost from the sum of the discounted cash flows and can be considered as the expected profit of the investment. Unlike the payback time, it takes the time value of money and all the relevant cash flows over a predefined period into account. The Internal Rate of Return (IRR), the discount rate at which the NPV is zero, gives an idea about the relative return of the investment but doesn't take the scale of the project into account: while the IRR of two projects can be the same, the NPV of one project can be larger than the NPV of the other. Therefore, we prefered to use the NPV approach to determine the economic feasibility of installing a CHP system. The next paragraphs give more insight in the calculation of the NPV, defined as follows [17]:

$\mathrm{NPV}_{t}=\sum_{t=1}^{n}\left[\frac{(1-b)\left(O_{t}-Q_{t}\right)+b A_{t}}{(1+i)^{t}}\right]-I_{0}$

\subsection{The environmental aspect: energy use and air quality}

In order to analyze the primary energy saving (PES) of a CHP system, often a comparison of the efficiencies between a CHP system and divided generation is made [18-20]. PES can be defined as presented in Eq. (2), with $\eta_{Q}^{\text {SP }}$ representing the efficiency of 
Table 1

Overview economic analyses.

\begin{tabular}{llllll}
\hline CHP technology & $\begin{array}{l}\text { Electrical } \\
\text { output }\end{array}$ & NPV (in 1000 \$) & PBT & IRR & Reference \\
\hline Steam turbine & $15-17 \mathrm{MW}$ & $95000.00(20 \mathrm{yrs})$ & $2.5 \mathrm{yrs}$ & $/$ & {$[13]$} \\
Gas engine & $2 \times 1.3 \mathrm{MW}$ & $/$ & $2.8 \mathrm{yrs}$ & $47 \%$ & {$[14]$} \\
& $66 \mathrm{~kW}$ & $/$ & $2.6 \mathrm{yrs}$ & $39 \%$ & \\
Diesel engine & $975 \mathrm{~kW}$ & $980.18(20 \mathrm{yrs})$ & $6.1 \mathrm{yrs}$ & $24 \%$ & {$[15]$} \\
& $1300 \mathrm{~kW}$ & $1204.50(20 \mathrm{yrs})$ & $6.4 \mathrm{yrs}$ & $23 \%$ & \\
& $1640 \mathrm{~kW}$ & $1316.46(20 \mathrm{yrs})$ & $6.8 \mathrm{yrs}$ & $22 \%$ & \\
Gas engine & $120 \mathrm{~kW}$ & $/$ & $4.4 \mathrm{yrs}$ & $17 \%$ & {$[16]$} \\
\hline
\end{tabular}

a boiler and $\eta_{E}^{S P}$ representing the efficiency of a power plant. $F^{S P}$ represents the fuel thermal input to the separate production (SP) of the cogenerated electricity $\left(E^{Y}\right)$ and heat $\left(Q^{Y}\right) . F^{Y}$ represents the fuel thermal input to the cogeneration. The larger the efficiency of the CHP system, the more primary energy is saved [18].

$\mathrm{PES}=\frac{F^{\mathrm{SP}}-F^{Y}}{F^{\mathrm{SP}}}=1-\frac{F^{Y}}{E^{Y} / \eta_{E}^{\mathrm{SP}}+Q^{Y} / \eta_{Q}^{\mathrm{SP}}}$

By calculating PES, the fuel inputs to the different systems are not taken into account, only the efficiencies are considered. Therefore, the ' $\mathrm{CO}_{2}$ emission reduction indicator' $\left(\mathrm{CO}_{2} \mathrm{ER}\right)$ is introduced [18]:

$$
\mathrm{CO}_{2} \mathrm{ER}=\frac{m_{X}^{\mathrm{SP}}-m_{X}^{Y}}{m_{X}^{\mathrm{SP}}}=1-\frac{\mu_{\mathrm{XE}}^{Y} E^{Y}}{\mu_{\mathrm{XE}}^{\mathrm{SP}} E^{Y}+\mu_{\mathrm{XQ}}^{\mathrm{SP}} Q^{Y}}
$$

With $m_{X}^{Y}$ representing the mass of a pollutant $X$ emitted by cogeneration and with $m_{X}^{\mathrm{SP}}$ as the mass of a pollutant $X$ emitted by the SP of the same amount of electricity and heat. $\mu_{\mathrm{XE}}^{\mathrm{SP}}$ and $\mu_{\mathrm{XQ}}^{\mathrm{SP}}$ are the energy output related emission factors of pollutant $X$ for the SP of electricity and heat. $\mu_{\mathrm{XE}}^{Y}$ represents the electrical output related emission factor for the CHP system. When the same fuel input is assumed for cogeneration as well as for SP, the PES indicator and the $\mathrm{CO}_{2} \mathrm{ER}$ indicator bring the same result [18].

Increasing the efficiency of the fuel utilization is one way of reducing the $\mathrm{CO}_{2}$ emission for a certain amount of energy production. Another way is to use the produced $\mathrm{CO}_{2}$ in a process. $\mathrm{CO}_{2}$ is recovered from the engine exhaust gases and when passed through a catalytic converter, the $\mathrm{CO}_{2}$ can provide atmosphere enrichment in greenhouses [10,11]. A catalytic converter reduces $\mathrm{NO}_{X}$ emissions by $80-90 \%$ and $\mathrm{CO}$ emissions by about $80 \%$ [20]. Also a local and global emission balance can be established to determine the environmental impact. Such balances determine the $\mathrm{CO}_{2}$ emission reduction in absolute figures [12]. While the population's health can be directly affected by $\mathrm{NO}_{X}$ and $\mathrm{CO}, \mathrm{CO}_{2}$ emissions cause global warming and hence have no effect on local air quality. This global approach is similar to the one used to evaluate the energy saving: the $\mathrm{CO}_{2}$ emission of the CHP system is compared with the $\mathrm{CO}_{2}$ emission of the separate production of the same amount of heat and power. The global balance for pollutant $X$ is defined as follows [20]:

$\Delta m_{X}=m_{X}^{Y}-m_{\mathrm{XE}}^{\mathrm{SP}}-m_{\mathrm{XQ}}^{\mathrm{SP}}=\mu_{\mathrm{XE}}^{Y} E^{Y}-\mu_{\mathrm{XE}}^{\mathrm{SP}} E^{Y}-\mu_{\mathrm{XQ}}^{\mathrm{SP}} Q^{Y}$

Where $\Delta m_{X}$ is the mass difference of emitted pollutant $X$, due to cogeneration. If $\Delta m_{X}$ is positive, cogeneration causes an increase in $X$ emissions, compared to the SP of the same quantity of electricity and heat. $m_{\mathrm{XE}}^{\mathrm{SP}}$ is the mass of pollutant $X$ emitted by a power plant for the separate production of the same quantity of electricity produced by cogeneration. $m_{\mathrm{XQ}}^{\mathrm{SP}}$ is the mass of pollutant $X$ emitted by a boiler for the separate production of the same quantity of heat as produced by cogeneration. The impact on $\mathrm{NO}_{X}$ and $\mathrm{CO}$ emissions of installing a CHP system has to be measured on a local scale and therefore, the emissions of these gases avoided by the power plant are excluded. The local emission balance is presented as follows [20]:

$$
\Delta m_{X}=m_{X}^{Y}-m_{\mathrm{XQ}}^{\mathrm{SP}}
$$

\subsection{Technical feasibility}

Because the technical feasibility of the CHP system falls beyond the scope of this study, the determination of the CHP capacity is only explained briefly. The electric capacity of the CHP system to be installed can be determined by investigating the relationship between the needed thermal or electric load and the duration (hours per year) [20]. This annual duration curve presents the size of the CHP unit to be installed and the expected annual operation time]. The optimal CHP capacity is the one by which most of the energy produced, is utilized and by which only a small amount of energy needed, has to be produced separately [21,22].

\section{Case studies}

In 2001, the Belgian federal government and the Belgian districts entered into a Cooperation Agreement concerning climate policy. The target of the Flemish district, the northern part of Belgium, is to reduce greenhouse gas emissions with $5.2 \%$. Therefore, a reduction of 22.2 million ton $\mathrm{CO}_{2}$-equivalents is needed. As a contribution to this CHP objective, the agricultural sector committed itself to install $112 \mathrm{MW}_{\mathrm{e}}-185 \mathrm{MW}_{\mathrm{e}}$ of CHP capacity in the greenhouse sector [23]. After all, in 2005, the greenhouse sector had a share of $70 \%$ in the total energy use of the Flemish agriculture [24].

This section will compare the economic feasibility and the environmental impact of installing a CHP system for two greenhouse horticulturists. One case study concerns the cultivation of tomatoes, a crop that demands a high amount of heat and a low amount of electricity. The other case study investigates the same aspects for lettuce: a crop with a lower need for heat but a higher electricity demand, due to use of assimilation lighting.

\subsection{Energy need and dimensioning of the CHP system}

It is assumed that both CHP systems are powered by a gas fuelled internal combustion engine. The flue gasses first pass through a catalytic converter and a condenser before entering the greenhouse. The catalytic converter purifies the flue gasses so that it can be used for $\mathrm{CO}_{2}$ enrichment. Heat is not only recovered from the cooling circuit. By installing a cooler and condenser heat is retrieved from the flue gasses as well, resulting in a higher thermal efficiency of the CHP system. Also a buffer is added: the CHP can run during the day, when electricity prices are high. Excess heat is stored in the buffer and can be released in the greenhouse during the night [25]. An auxiliary boiler is used if the cogenerated heat does not cover the total heat demand. Excess electricity is sold to the grid. Fig. 1 shows the flow diagram of the CHP system. For both crops, the flow diagram is assumed the same.

The capacity of the CHP system is determined by investigating the relationship between the energy need and the duration of this need [20]. The tomato crop has an annual electric demand of $131 \mathrm{MWh}_{\mathrm{e}}$ and an annual heat demand of $6388 \mathrm{MWh}_{\text {th }}$. Heat is for $61 \%$ provided by a boiler on extra heavy oil (EHO), a gas fuelled boiler fills in the remaining heat demand. The cultivation of lettuce demands four times less heat (1452 $\mathrm{MWh}_{\text {th }}$ annually) but, due to the utilization of assimilation lighting, consumes more electricity $\left(549 \mathrm{MWh}_{\mathrm{e}}\right)$ than the tomato crop. Using the power-heat ratio 


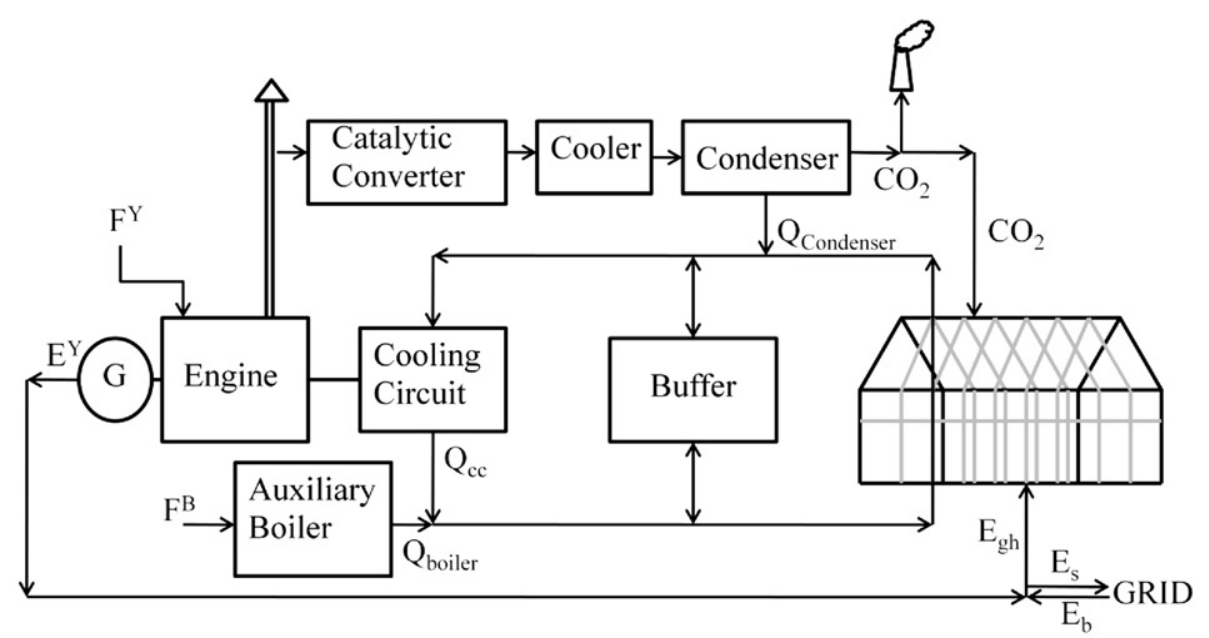

Based on $[20,26]$

Fig. 1. Flow diagram of the CHP system. Based on $[20,26]$.

(0.70), the electric capacity of the CHP system for the tomato crop could be derived from the thermal capacity. The horticulturist should install a CHP system of $1.2 \mathrm{MW}_{\mathrm{e}}$. Growing lettuce demands less energy (sum of heat and electricity) than growing tomatoes and for this reason a smaller CHP system will be required. The horticulturist should place a CHP system with a capacity of $239 \mathrm{~kW}_{\mathrm{e}}$. Table 2 gives an overview of the characteristics of the CHP systems of both crops. Due to monthly variations in demand, the monthly energy produced by the CHP system does not always cover the needed energy. Therefore, during certain months, electricity has to be bought and heat has to be provided by the auxiliary boiler as required.

The estimated production profile of the CHP system for the tomato crop is based on the production profile of a similar CHP system installed at the greenhouse of a similar tomato grower. The latter tomato grower has a cultivated area of 1 ha and installed a CHP system of $1.4 \mathrm{MW}_{\mathrm{e}}$. The estimated production profile of this CHP system is based on the heat demand of the tomato crop. Concerning the lettuce crop, specific data was obtained concerning the time electricity is needed. Therefore, the production profile of the CHP system for lettuce is based on the monthly electricity demand of the lettuce grower. Table 3 gives an overview of the estimated production profile of the CHP system of both crops.

\subsection{Economic aspects: the Net Present Value (NPV)}

Table 4 provides the data necessary to calculate the NPV. The capital cost consists of the cost of the CHP system, a catalytic converter, a buffer to store excess heat, a flue gas cooler and condenser (which enables the CHP system to provide more heat) and the connections to the gas and electricity grid. The outgoing cash flows $\left(Q_{t}\right)$ comprise fuel costs for CHP and boiler and annual operational and maintenance costs for $\mathrm{CHP}$ and catalytic converter. Annual incoming cash flows $\left(O_{t}\right)$ include the cost saving on the energy account (value of heat recovery and produced electricity), governmental support and the return on sales of CHP certificates. Both horticulturists will obtain CHP certificates. These certificates can be sold to power plants with a certificate duty. The CHP system and the catalytic converter can be considered for an investment allowance of $13.5 \%$ and the Flemish government also supports investing in a CHP system by granting an interest-rate subsidy of $4 \%$. The NPV is determined by applying Eq. (1). For calculating the annual depreciation amount - having only an indirect effect through taxes - the double declining method is used. The discount rate is set at 3\%, the tax on profit at 33.99\%. The lifetime of the CHP system is assumed to be 10 years. As demonstrated in Table 4 , the NPV is positive for both horticulturists, investing in a CHP system is economically feasible. Mind that the internal rate of return (IRR) of the CHP system for the tomato crop is 33\%, while the IRR of the CHP system for the lettuce crop is $16 \%$. Analyzing the NPV and the IRR of both self-managed CHP systems, we can assume the existence of increasing economies of scale.

\subsection{Monte Carlo sensitivity analysis}

To examine how the NPV varies when the value of uncertain assumptions is modified, a Monte Carlo sensitivity analysis is performed using the software program Crystal Ball. When performing a Monte Carlo sensitivity analysis, probability distributions are specified for uncertain values of model input parameters. Then multiple trials are executed, taking each time a random draw from the distribution for each parameter. Each trial, the output is

Table 2

Characteristics of the CHP systems.

\begin{tabular}{|c|c|c|}
\hline CHP system & Tomato & Lettuce \\
\hline Electric capacity $\left(\mathrm{kW}_{\mathrm{e}}\right)$ & 1263 & 239 \\
\hline Electric efficiency & $39 \%$ & $35 \%$ \\
\hline Thermal efficiency (without condenser) & $46 \%$ & $50 \%$ \\
\hline Thermal efficiency (with condenser) & $56 \%$ & $60 \%$ \\
\hline Thermal capacity $\left(\mathrm{kW}_{\mathrm{th}}\right)$ & 1812 & 414 \\
\hline$F^{Y}(\mathrm{MWh})$ & 17931 & 2286 \\
\hline$F^{B}(\mathrm{MWh})$ & 298 & 263 \\
\hline \multicolumn{3}{|l|}{ Energy demand } \\
\hline Heat $\left(\mathrm{MWh}_{\mathrm{th}}\right)$ & 6388 & 1452 \\
\hline Electricity $\left(\mathrm{MWh}_{\mathrm{e}}\right)$ & 131 & 549 \\
\hline \multicolumn{3}{|l|}{ Energy produced by the CHP system } \\
\hline$Q_{c c}\left(M h_{t h}\right)$ & 8248 & 1143 \\
\hline$Q_{\text {cond. }}\left(\mathrm{MWh}_{\mathrm{th}}\right)$ & 1792 & 229 \\
\hline$Q^{Y}\left(\mathrm{MWh}_{\mathrm{th}}\right)$ & 10040 & 1372 \\
\hline$E^{Y}\left(\mathrm{MWh}_{\mathrm{e}}\right)$ & 6995 & 795 \\
\hline \multicolumn{3}{|c|}{ Energy demanded not covered by the CHP system } \\
\hline $\mathrm{Qb}_{\mathrm{b}}\left(\mathrm{MWh}_{\mathrm{th}}\right)$ & 268 & 237 \\
\hline$E_{\mathrm{b}}\left(\mathrm{MWh}_{\mathrm{e}}\right)$ & 1 & 28 \\
\hline \multicolumn{3}{|c|}{ Excess electricity produced by the CHP system } \\
\hline$E_{\mathrm{s}}\left(\mathrm{MWh}_{\mathrm{e}}\right)$ & 6864 & 274 \\
\hline
\end{tabular}


Table 3

Estimated production profile CHP systems.

\begin{tabular}{lcc}
\hline Month & $\begin{array}{l}\text { Operating hours CHP } \\
\text { Tomato crop }\end{array}$ & $\begin{array}{l}\text { Operating hours CHP } \\
\text { Lettuce crop }\end{array}$ \\
\hline January & 651 & 402 \\
February & 609 & 291 \\
March & 617 & 217 \\
April & 510 & 48 \\
May & 402 & 272 \\
June & 357 & 335 \\
July & 341 & 315 \\
August & 341 & 362 \\
September & 376 & 160 \\
October & 455 & 302 \\
November & 390 & 378 \\
December & 491 & 245 \\
Total & 5540 & 3326 \\
\hline
\end{tabular}

calculated for each set of specified values. After all the trials are executed, a probability distribution of the model output is obtained [27]. By applying this risk model, not consequences but risks are compared and hence, more information is obtained as compared to when a conventional, static model is applied. When probability distributions for several defined assumptions are specified, uncertainties are incorporated in the model. Moreover, the results of the model not only incorporate the uncertainties of the input parameters, they also give us their importance [16].

To know how important the establishment of a CHP certificate market and governmental support is for the investment to become profitable, triangular distributions are set up for the value of a CHP certificate and the interest-rate subsidy. Because income and costs depend on the amount of energy produced, it is necessary to know how large the impact of the electric and thermal efficiencies is on the economic feasibility. Therefore, the total efficiency of the CHP system is also a parameter that is varied. Energy prices are established by the market and hence uncertain. For this reason, also for the fuel prices a triangular distribution is established. By specifying those triangular distributions, the values near the most plausible estimate are given more weight. The minimum, maximum and most plausible value specified for each parameter, are summarized in Table 5. The simulation is run twice. The first time, the value of a CHP certificate is varied between $€ 27$, the guaranteed minimum and $€ 43$. $€ 43$ is the fee to be paid by electricity producers when they don't fulfill their certificate duty. The most plausible value is set at 41.85 , being the average value at which a certificate is traded. The second time, the CHP certificate value is varied under the assumption that there's no guaranteed minimum. The determination of the minimum, most plausible and maximum value of the other uncertain parameters is based on expert knowledge and

Table 4

Economic analysis $(€)$.

\begin{tabular}{lcc}
\hline & Tomato crop & Lettuce crop \\
\hline Capital cost & $1,214,358$ & 397,772 \\
Annual outgoing cash flows & & \\
Annual maintenance cost & 219,443 & 31,406 \\
Annual fuel cost & 546,864 & 71,615 \\
Annual incoming cash flows & & \\
Annual fuel saving & 334,666 & 87,303 \\
Annual electricity income & 495,096 & 55,385 \\
Annual average certificate income & 287,350 & 33,505 \\
Annual average interest rate subsidy (4\%) & 22,000 & 8293 \\
Investment allowance (13,5\%) & 46,323 & 15,828 \\
Sum of discounted net cash flows & $2,499,989$ & 563,174 \\
NPV & $1,331,954$ & 181,230 \\
\hline
\end{tabular}

Table 5

Minimum, most plausible and maximum value of uncertain parameters.

\begin{tabular}{lccc}
\hline & $\begin{array}{l}\text { Minimum } \\
\text { value }\end{array}$ & $\begin{array}{l}\text { Most plausible } \\
\text { value }\end{array}$ & $\begin{array}{l}\text { Maximum } \\
\text { value }\end{array}$ \\
\hline CHP certificate $(€ /$ certificate) & 27.00 & 41.85 & 43.00 \\
CHP certificate $(€ /$ certificate) & 0.00 & 41.85 & 43.00 \\
Gas price $(€ /$ MWh) & 24.00 & 30.00 & 44.00 \\
Price extra heavy oil ( $€ /$ ton $)$ & 306.96 & 383.70 & 562.76 \\
Interest-rate subsidy (\%) & 0.00 & 4.00 & 4.00 \\
Total efficiency (\%) & 80.00 & 95.00 & 98.00 \\
\hline
\end{tabular}

statistical data. The most plausible value is the value used in the base case scenario. After the distributions are established, 10,000 trials, taking each time a random draw from the distribution for each assumption are executed in order to produce a large number of NPVs and their distribution. The results of the sensitivity analysis are presented in Table 6.

In the first analysis, regarding the tomato crop, there is a $98.97 \%$ probability of a positive NPV. Concerning the lettuce crop, the probability of a positive NPV is lower: $87.72 \%$. For both crops, variations in the NPV are primarily due to variations in the total efficiency (sum of electrical efficiency and thermal efficiency) of the CHP system. Concerning the tomato crop, the variation in the NPV can be explained for $68.3 \%$ by the variation in the total efficiency and for $22.3 \%$ by variations in the gas price. With regards to the lettuce crop, the variation in the total efficiency of the CHP system explains for $72 \%$ the variability in the NPV. The rate at which the variation in the value of a CHP certificate explains the variation in the NPV is for both crops low: $8.6 \%$ regarding the tomato crop, $3.3 \%$ regarding the lettuce crop. The relationship between the total efficiency of the CHP system and the NPV is positive: when the total efficiency increases, the NPV increases as well. The relationship between the gas price and the NPV, however, is different for both crops. It is considered that because both gas and electricity prices are influenced by the price of crude oil, the electricity price is linked to the gas price. Concerning the tomato crop, both the avoided separate production and the fuel input are valued at the gas price. In this case, an increase in the gas price will have a positive effect on the NPV. An increase in the gas price increases the value of the avoided separate production of heat and because of the link between gas and electricity price, also the return from the electricity sold increases. The augmentation of these incoming cash flows seems to compensate the increase of the fuel cost and therefore, a positive relationship between the gas price and the NPV is reported for the tomato grower. Regarding the lettuce crop, this relationship is negative, when the gas price increases, the NPV will diminish. Note that without a CHP system, the lettuce grower uses a boiler on EHO to heat the greenhouse. When a CHP system is

Table 6

Results of the sensitivity analysis for both crops

\begin{tabular}{|c|c|c|c|c|c|}
\hline \multicolumn{3}{|c|}{$\begin{array}{l}\text { CHP certificate: guaranteed } \\
\text { minimum value of } € 27\end{array}$} & \multicolumn{3}{|c|}{$\begin{array}{l}\text { CHP certificate: no } \\
\text { guaranteed minimum value }\end{array}$} \\
\hline \multicolumn{3}{|c|}{ Probability of a positive NPV (\%) } & \multicolumn{3}{|c|}{ Probability of a positive NPV (\%) } \\
\hline Tomato crop & Lettuc & e crop & Tomato crop & & tuce crop \\
\hline 98.97 & 87.72 & & 87.46 & & 67 \\
\hline \multicolumn{6}{|c|}{ \% Share in explanation of variation in NPV (relationship with NPV) } \\
\hline & $\begin{array}{l}\text { Tomato } \\
\text { crop }\end{array}$ & $\begin{array}{l}\text { Lettuce } \\
\text { crop }\end{array}$ & & $\begin{array}{l}\text { Tomato } \\
\text { crop }\end{array}$ & $\begin{array}{l}\text { Lettuce } \\
\text { crop }\end{array}$ \\
\hline Total efficiency & $68.3(+)$ & $72.0(+)$ & Total efficiency & $34.9(+)$ & $55.1(+)$ \\
\hline Gas price & $22.3(+)$ & $3.3(-)$ & Gas price & $16.3(+)$ & $2.4(-)$ \\
\hline Price EHO & I & $19.2(+)$ & Price EHO & 1 & $17.5(+)$ \\
\hline CHP certificate & $8.6(+)$ & $3.3(+)$ & CHP certificate & $48.6(+)$ & $23.1(+)$ \\
\hline Interest subsidy & $0.8(+)$ & $2.3(+)$ & Interest subsidy & $0.2(+)$ & $1.8(+)$ \\
\hline
\end{tabular}


installed, the horticulturist can use the heat recovered from the engine. Hence, the avoided separate production of heat is valued at the price of EHO and the fuel input of the CHP system is valued at the gas price. Table 6 demonstrates that when the price of EHO increases, the NPV will increase as well. When the value of a CHP certificate is varied between $€ 0$ and $€ 43$, the probability of a positive NPV decreases. With regards to the tomato crop, there's a $87.46 \%$ probability, concerning the lettuce crop, the probability of a positive NPV is reduced to $74.67 \%$. Moreover, the share each parameter has in the explanation of the variation in the NPV of the tomato crop, is changed. The variation in the CHP certificate value (48.6\%) explains the variation in the NPV to a larger extent than the variation in the total efficiency (34.9\%). With regards to the lettuce crop, the variation in total efficiency explains the variation in the NPV for $55.1 \%$ the rate at which the variation in the value of a CHP certificate explains the variation in the NPV equals $23.1 \%$. Note that these modifications are due to the use of different ranges. If the range in which the value of a certain parameter varies, increases, then, the extent to which that parameter explains the variation in the NPV increases as well.

The results demonstrate that it is important to have a guaranteed minimum value for a CHP certificate. When all the certificate duties are fulfilled and when horticulturists don't have the opportunity to sell their CHP certificates at a sufficiently high price, they lose an important source of income and hence the probability of a positive NPV decreases. Although smaller, the variation in total efficiency remains to have an important share in the explanation of the variation in the NPV. unlike the electrical efficiency, the thermal efficiency can be controlled by the horticulturist. By using heat circuits of different temperatures and by investing in a flue gas condenser, the horticulturist could increase the thermal efficiency of the CHP system. Because gas and electricity prices are determined by the market, the horticulturist cannot exert an influence on it, these factors remain uncertain.

\subsection{Environmental aspect: energy use and air quality}

Using the efficiencies listed in Table 2 and supposing an efficiency of $90 \%$ for a boiler and an efficiency of 55\% for a power plant, a PES of $25 \%$ is obtained when the tomato grower installs a CHP system with condenser. Concerning the lettuce crop, the PES equals $23 \%$. While for the PES indicator only the efficiencies of each system are relevant, the $\mathrm{CO}_{2} \mathrm{ER}$ indicator as presented by Eq. (3), also takes the fuel inputs of the different systems into account. In this study, emission factors for an electricity plant are calculated by using data, presented in Table 7. The used emission factors for a gas-uelled boiler and CHP system are based on the figures presented in the CHP manual of Cogen Europe [20]. Emission factors for a boiler fuelled with EHO are found in [28]. Table 8 gives an overview of the emission factors. The $\mathrm{CO}_{2}$ ER demonstrates that due to the use of gas instead of $\mathrm{EHO}$, the impact of installing a $\mathrm{CHP}$ on air quality is larger than the impact on energy use. For the tomato crop, the $\mathrm{CO}_{2}$ emissions are reduced by $30 \%$, the $\mathrm{CO}_{2}$ ER concerning the lettuce crop equals $39 \%$.

Table 7

Emissions factors of the electricity production in Flanders in 2005 [29-31].

Electricity production (Thermal central $38.8 \%$, Nuclear $40.2 \%$, CHP $20.9 \%$ ) 57.7 TWh

\begin{tabular}{lll}
\hline Emitted gasses & Emission (ton) & Emission factor: $\mu$ XE $(\mathrm{g} / \mathrm{kWhe})$ \\
\hline $\mathrm{CO}_{2}$ & $23,847,000$ & 413.29 \\
$\mathrm{CO}$ & 7487 & 0.13 \\
$\mathrm{NO}_{\mathrm{X}}$ & 30345 & 0.53 \\
\hline
\end{tabular}

Table 8

Overview of used emission factors $[20,28]$.

\begin{tabular}{lcccc}
\hline $\begin{array}{l}\text { Pollutant } \\
(\mathrm{X})\end{array}$ & $\begin{array}{l}\mathrm{CHP}-\text { gas: } \mu_{\mathrm{XE}}^{\mathrm{Y}} \\
(\mathrm{g} / \mathrm{kWh} \mathrm{e})[20]\end{array}$ & $\begin{array}{l}\text { Boiler }-\mathrm{EHO}: \mu_{\mathrm{XQ}}^{\mathrm{SP}} \\
\left(\mathrm{g} / \mathrm{kWh}_{\mathrm{th}}\right)[28]\end{array}$ & $\begin{array}{l}\text { Boiler }- \text { gas: } \mu_{\mathrm{XQ}}^{\mathrm{SP}} \\
\left(\mathrm{g} / \mathrm{kWh}_{\mathrm{th}}\right)[20]\end{array}$ & $\begin{array}{l}\text { Power plant: } \\
\mu_{\mathrm{XE}}^{\mathrm{SP}}\left(\mathrm{g} / \mathrm{kWh}_{\mathrm{e}}\right)\end{array}$ \\
\hline $\mathrm{CO}_{2}$ & 577.26 & 306.40 & 252.55 & 335.96 \\
$\mathrm{CO}$ & 2.80 & 0.10 & 0.03 & 0.13 \\
$\mathrm{NO}_{\mathrm{x}}$ & 1.90 & 0.72 & 0.19 & 0.53 \\
\hline
\end{tabular}

The difference in the emission of $\mathrm{CO}_{2}$ ( $\mathrm{CHP}$ compared to SP) can also be estimated by establishing a global emission balance like presented by Eq. (4). A local balance as shown in Eq. (5) is set up concerning the emissions of $\mathrm{NO}_{x}$ and $\mathrm{CO}$. Table 9 explains in detail the calculation of the global $\mathrm{CO}_{2}$ emission balance for the tomato crop. The local emission balances and the results for the lettuce crop are calculated analogously and are shown in Table 10. Regarding the tomato crop, the cogenerated heat and electricity (listed in Table 2) will cause an annual emission of 4105 ton $\mathrm{CO}_{2}$, including the emission of the boiler (4037.65 ton +67.68 ton). Without a CHP system, generating the same amount of heat and electricity would result in an emission of 5213.10 ton $\mathrm{CO}_{2}$ $(998.90$ ton +1864.36 ton +2349.84 ton $)$. In this case, the global emission, demonstrates that, annually, 1108 ton $\mathrm{CO}_{2}$ are emitted less than when the same amount of heat and electricity is generated separately. Concerning the lettuce crop, the global emission balance presents an annual reduction of 207 ton $\mathrm{CO}_{2}$. The emissions of $\mathrm{NO}_{x}$ and $\mathrm{CO}$ only have an impact on local scale. For both crops, a small increase in the emission of these gasses is observed when placing a CHP system.

Based on figures found in the Agricultural Report written by the Flemish government [32], annual production for each crop is estimated. Annually, 666 ton tomatoes and 364 ton lettuce would be produced by the considered horticulturists. If the tomato grower installs a CHP system, a 1.66 ton $\mathrm{CO}_{2}$ reduction per ton tomatoes produced is observed. Installing a CHP system for growing lettuce, per ton lettuce produced, $\mathrm{CO}_{2}$ emission are reduced with 0.57 ton. These figures confirm that for both crops, the same production output can be achieved creating less waste. The eco-efficiency of installing a CHP system at the greenhouse of the tomato grower is larger than for the lettuce grower. Also $\mathrm{CO}_{2}$ reduction in terms of the investment cost shows that the potential for $\mathrm{CO}_{2}$ reduction is larger for the tomato crop than for the lettuce crop. Concerning the tomato crop, per euro invested, $\mathrm{CO}_{2}$ is reduced with $0.91 \mathrm{~kg}$. A $0.51 \mathrm{~kg} \mathrm{CO} 2$ reduction per euro invested is observed for the lettuce crop.

These results demonstrate that placing CHP systems on a large scale can contribute to the realization of a 22.2 million ton $\mathrm{CO}_{2}$ equivalents reduction, the objective set by the Flemish district. Moreover, concerning air quality, the greenhouse sector has a step ahead compared to the industrial sector. The horticulturist could use the $\mathrm{CO}_{2}$ for atmosphere enrichment in the greenhouse and hence, not all of the $\mathrm{CO}_{2}$ produced by the $\mathrm{CHP}$ system will be

Table 9

Determination of the global $\mathrm{CO}_{2}$ emission balance for the tomato crop.

\begin{tabular}{ll}
\hline $\mathrm{CO}_{2}$ & $\begin{array}{l}\text { Energy output/input (MWh) } \times \text { Emission } \\
\text { factor }(\mathrm{kg} / \mathrm{MWh})=\text { Emission (ton) }\end{array}$ \\
\hline Emission CHP (ton) & $6995 \times 577.26=4037.65$ \\
+ Emission Boiler (ton) & $268 \times 252.55=67.68$ \\
-Avoided emission gas (ton) & $3955 \times 252.55=998.90$ \\
-Avoided emission EHO (ton) & $6085 \times 306.40=1864.36$ \\
= Local emission balance (ton) & 1242.08 \\
-Avoided emission power plant (ton) & $6995 \times 335.96=2349.84$ \\
=Global emission balance (ton) & -1107.76 \\
\hline
\end{tabular}


Table 10

Determination of the local and global emissions balance.

\begin{tabular}{|c|c|c|c|c|c|c|c|c|c|}
\hline & Pollutant & $\begin{array}{l}\text { Emission } \\
\text { CHP (ton) }\end{array}$ & $\begin{array}{l}\text { Emission gas } \\
\text { boiler (ton) }\end{array}$ & $\begin{array}{l}\text { Emission boiler } \\
\text { on EHO (ton) }\end{array}$ & $\begin{array}{l}\text { Avoided emission } \\
\text { boiler on gas (ton) }\end{array}$ & $\begin{array}{l}\text { Avoided emission } \\
\text { boiler on EHO (ton) }\end{array}$ & $\begin{array}{l}\text { Local emission } \\
\text { balance (ton) }\end{array}$ & $\begin{array}{l}\text { Avoided emission } \\
\text { power plant }\end{array}$ & $\begin{array}{l}\text { Global emission } \\
\text { balance (ton) }\end{array}$ \\
\hline \multicolumn{10}{|c|}{ Tomato crop } \\
\hline & 1 & 2 & 3 & 4 & 5 & 6 & 7 & 8 & 9 \\
\hline 1 & $\mathrm{CO}_{2}$ & 4037.65 & 67.68 & 1 & 998.90 & 1864.36 & 1242.08 & 2349.84 & -1107.76 \\
\hline 2 & $\mathrm{CO}$ & 19.58 & 0.01 & I & 0.12 & 0.58 & 19.41 & 1 & 1 \\
\hline 3 & $\mathrm{NO}_{x}$ & 13.29 & 0.05 & 1 & 0.75 & 4.37 & 12.22 & 1 & 1 \\
\hline \multicolumn{10}{|c|}{ Lettuce crop } \\
\hline 4 & $\mathrm{CO}_{2}$ & 458.92 & 1 & 23.28 & 1 & 421.76 & 60.44 & 267.08 & -206.64 \\
\hline 5 & $\mathrm{CO}$ & 2.23 & 1 & 0.01 & 1 & 0.13 & 2.10 & 1 & 1 \\
\hline 6 & $\mathrm{NO}_{x}$ & 1.51 & 1 & 0.05 & 1 & 0.99 & 0.58 & i & 1 \\
\hline
\end{tabular}

emitted in the atmosphere. The annual production of tomatoes is estimated at 666 ton [32], consuming about 565 ton $\mathrm{CO}_{2}$. Therefore, applying the global emission balance, an annual reduction of 1673 ton $\mathrm{CO}_{2}$ is estimated. For an estimated annual production of 364 ton [32], the lettuce crop needs 175 ton $\mathrm{CO}_{2}$, resulting in an annual reduction of 382 ton $\mathrm{CO}_{2}$ when a CHP system is placed. Installing a catalytic converter will also result in a $80 \%$ lower emission of $\mathrm{CO}$ and the $\mathrm{NO}_{x}$ emission will be reduced by $80-90 \%$ [20]. For both crops, the local emission balance will show an increase of $\mathrm{NO}_{x}$ and $\mathrm{CO}$ gasses emitted when a CHP system is placed. Due to the catalytic converter, the increase of CO gasses is limited to 3.90 ton a year regarding the tomato crop and 0.45 ton a year regarding the lettuce crop. Concerning the $\mathrm{NO}_{x}$ emission, an annual increase of 1.99 ton and 0.23 ton is calculated for the tomato and lettuce crop respectively.

\section{Conclusion and discussion}

Global and local emission reduction commitments and the energy market liberalization motivate the analysis of the sustainability of a self-managed Combined Heat and Power (CHP) system for greenhouse cultivation. Using two case studies, this paper aims to highlight that for two different crops, investing in a CHP system is economic feasible and environment-friendly but to a different extent.

Because of a lower energy need, the capacity of the CHP system is smaller for the lettuce crop than for the tomato crop. The lettuce grower should install a CHP system of $239 \mathrm{~kW}$, the tomato grower one of 1.2 MW. For both horticulturists, investing in a CHP system is economically viable, as demonstrated by a positive NPV. The sensitivity analyses demonstrated that the efficiency of a CHP system has a large influence on the economic feasibility. Because the horticulturist cannot control it, a guaranteed electric efficiency is an important issue when negotiating with the technology provider. Also a guaranteed minimum value for a CHP certificate seems to be indispensable in order to make the investment in CHP profitable. The presented case studies prove that investing in a CHP system is economic justified. Moreover, self-managing a CHP system has the advantage of the horticulturist not being dependent on the decisions made by external parties and the operation of the CHP system can be outlined by the horticulturist himself.

Concerning the environmental impact, when investing in a CHP system, a Primary Energy Saving of more than 20\% would be realized regarding both crops. Calculated relatively, the $\mathrm{CO}_{2}$ Emission Reduction amounts to $30 \%$ for the tomato crop and even $39 \%$ for the lettuce crop when a CHP system is compared to separate production of heat and electricity. The $\mathrm{CO}_{2} \mathrm{ER}$ is larger than the PES, because also the change of fuel input is taken into account. When applying a global emission balance, installing a CHP system would result in an annual reduction of 1673 ton $\mathrm{CO}_{2}$ for the tomato crop. For the lettuce crop, the $\mathrm{CO}_{2}$ emission will be reduced by 382 ton annually. Concerning the impact of placing a CHP system on the emissions of $\mathrm{NO}_{x}$ and $\mathrm{CO}$, a local emission balance was formed. For both cases, a slight rise in the emission of $\mathrm{NO}_{x}$ and $\mathrm{CO}$ can be notified. But because horticulturists need $\mathrm{CO}_{2}$ for atmosphere enrichment, a catalytic converter is added to the CHP system which also removes most of the $\mathrm{NO}_{x}$ and $\mathrm{CO}$ particles from the flue gasses. By calculating the eco-efficiency of installing a CHP system, it is demonstrated that the potential for $\mathrm{CO}_{2}$ reduction is larger concerning the tomato crop than the lettuce crop. While the investment cost of the CHP system for the tomato crop is three times larger than for the lettuce crop, the $\mathrm{CO}_{2}$ reduction is five times larger.

Our study shows that combined heat and power generation can be a cost effective technology in agriculture with an important contribution towards a low-carbon renewable energy sector. Moreover, CHP systems should be seen as a part of a larger portfolio of energy technology solutions. Remark that investments are needed in several clean energy technologies and in several sectors (energy, agriculture, building, etc.) to reach current policy targets.

The agricultural sector and especially greenhouse cultivation, can contribute to reach emission targets by installing CHP systems. This research showed that glass horticulturists can successfully opt for a self-managed CHP system. However, producing energy onfarm raises several new issues. In fact the farmer becomes an agricultural producer and an energy producer. This diversification can result in a higher income with a lower risk. On the other hand, new skills (technical and management skills) are needed. Moreover, higher investments are increasing the financial risk of farmers and can possibly increase the dependency towards financial institutions. Farmers can opt for independent energy production with a self-managed CHP system but user-friendly systems and regulation are needed to make this option a success. Corporation with existing energy producers can reduce financial risk and can reduce the need for technological and market knowledge of energy production. But farmers will logically lose independence. Also, at some places in Flanders, the horticulturists risk not to have access to the national grid network which means that they can't distribute their excess electricity. In any case, further communication of the benefits of CHP systems and CHP expansion are needed. Furthermore, best practice approaches and demonstration cases for different industrial and agricultural audiences are desirable to facilitate and to accelerate the energy production using CHP systems. Regulatory policy makers should be aware of the possibilities and the different requirements of combined heat and power technology solutions. Tailored policy and support measures can help to fill the lack of technical and economic applications and knowledge, and in this way overcome initial resistance.

\section{References}

[1] IPCC. Climate change 2007. Synthesis report. Geneva, Switzerland: IPCC. See also: http://www.ipcc.ch/publications_and_data/publications_ipcc_fourth_ assessment_report_synthesis_report.htm; 2007. 
[2] Stern. The economics of climate change, executive summary, UK. See also: http://news.bbc.co.uk/2/shared/bsp/hi/pdfs/30_10_06_exec_sum.pdf; 2006.

[3] European Commission. The Kyoto protocol and climate change. Brussels Belgium: European Commision. See also: http://www.europa-eu-un.org/ articles/en/article_1421_en.htm; 2002.

[4] EU commission. Citizens' summary. EU climate and energy package. European Commission. See also: http://ec.europa.eu/climateaction/docs/climateenergy_summary_en.pdf; 2008.

[5] Lund H. Renewable energy strategies for sustainable development. Energy 2007;32:912-9.

[6] OECD/IEA. Combined heat and power. evaluating the benefits of greater global investment. Paris, France: IEA. See also: http://www.iea.org/Textbase/Papers/ 2008/CHP_report.pdf; 2008.

[7] Ramírez CA, Patel M, Blok K. From fluid milk to milk powder: energy use and energy efficiency in the European dairy industry. Energy 2006;31:1984-2004.

[8] Bhattacharyya SC, Thang DN. Economic buy-back rates for electricity from cogeneration: case of sugar industry in Vietnam. Energy 2004;29:1039-51.

[9] Panno D, Messineo A, Dispenza A. Cogeneration plant in a pasta factory: energy saving and environmental benefit. Energy; 2007:746-54.

[10] Critten DL, Bailey BJ. A review of greenhouse engineering developments during the 1990s. Agricultural and Forest Meteorology 2002;122:1-22.

[11] Canova A, Chicco G, Genon G, Mancarella P. Emission characterization and evaluation of natural gas - fuelled cogeneration microturbines and internal combustion engines. Energy Conversion and Management 2008;49:2900-9.

[12] Omer AM. Focus on low carbon technologies: the positive solution. Renewable Sustain Energy Rev 2007;12:2331-57.

[13] Costa A, Paris J, Towers M, Browne T. Economics of trigeneration in a kraft pulp mill for enhanced energy efficiency and reduced GHG emissions. Energy 2007;32:474-81.

[14] Oh S, Lee H, Jung J, Kwak H. Optimal planning and economic evaluation of cogeneration system. Energy 2007;32:760-71.

[15] Khan K, Rasul M, Khan M. Energy conservation in buildings: cogeneration and cogeneration coupled with thermal-energy storage. Appl Energy 2004;77:15-34.

[16] Al-Mansour F, Kozuh M. Risk analysis for CHP decision making within the conditions of an open electricity market. Energy 2007;32:1905-16.

[17] Mercken R. De investeringsbeslissing. Een beleidsgerichte analyse. Apeldoorn: Garant: Antwerpen; 2004

[18] Chicco G, Mancarella P. Assessment of the greenhouse gas emissions from cogeneration and trigeneration systems. Part I: models and indicators. Energy 2008;33:410-7.

[19] Badami M, Casetti A, Campanile P, Anzioso F. Performance of an innovative 120 kWe natural gas cogeneration system. Energy 2007;32:823-33.

[20] Cogen Europe. EDUCOGEN. The European Educational Tool on Cogeneration. Consulted on 03.02.09 on: http://www.esco.co.ua/journal/2004_7/art125/ page1.htm; December 2001. Now available on: http://www2.vlaanderen.be/ economie/energiesparen/doc/wkk_basishandboekcogen.pdf; December 2001.
[21] Marbre A, Harvey S, Berntsson T. Technical, environmental and economic analysis of co-firing of gasified biofuel in a natural gas combined cycle (NGCC) combined heat and power (CHP) plant. Energy 2006;31:1614-31.

[22] Commission AMPERE. Main Report, section D4 Combined Heat and power [Hoofdrapport, sectie D4 Warmte - Kracht Koppeling]. Brussels, Belgium: Commission AMPERE. See also: http://mineco.fgov.be/energy/ampere commission/Rapport_fr.htm; 2000 (in Dutch).

[23] Flemish Government. Department LNE. The climate is changing. You too? Flemish Climate Policy 2006-2012 [Het klimaat verandert. U ook? Vlaams klimaatbeleidsplan 2006 - 2012]. See also: http://www.lne.be/themas/ klimaatverandering/toncontract/vkp_2006-2012_def.pdf; October 2006 (in Dutch).

[24] Flemish Environmental Organisation. Pocket-size indicators of the environment [Milieu-indicatoren in zakformaat]. See also: http://www.milieurapport. be/Upload/main/docs/Administrators/ZBMiraT2006web.pdf; November 2006 (in Dutch).

[25] Fragaki A, Andersen A, Toke D. Exploration of economical sizing of gas engine and thermal store for combined heat and power plants in the UK. Energy 2008;33:1659-70.

[26] General Electric Energy. It's in our nature. See also: http://www.gepower.com/ prod_serv/products/recip_engines/en/downloads/as_co2_eng.pdf.

[27] Boardman AE, Greenberg DH, Vining AR, Weimer DL. Cost benefit analysis. Upper Saddle River, New Jersey: Pearson Eduction, Inc.,; 2006. 560 pp.

[28] Derden A, Goovaerts L, Vercaemst P, Vrancken K. Best available techniques in the greenhouse sector [Beste beschikbare technieken (BBT) voor de glastuinbouw]. Gent: Academia Press. See also: http://www.emis.vito. be/EMIS/Media/bbt_rapport_glastuinbouw_volledig_rapport.pdf; 2005 (in Dutch).

[29] Flemish Environmental Organisation. ), Energetic production of power companies and petroleum refineries (Flanders, 1990-2006) [Energetische productie van de elektriciteitsbedrijven en de petroleumraffinaderijen (Vlaanderen, 1990-2006]. See also: http://www.milieurapport.be/default. aspx?PageID=86\&ChapID=2186\&NodeID=3741; December 2007 (in Dutch)

[30] Flemish Environmental Organization. Environmental data Mira-T 2007. Emissions to the air: greenhouse gasses [Kernset Milieudata Mira-T 2007. Emissies naar de lucht: broeikasgassen]. See also: http://www.milieurapport. be/Upload/main/docs/Administrators/MIRA-T\%202007/Kernset\%20T2007_emi ssies_lucht_broeikasgassen.xls; 2007 (in Dutch).

[31] Flemish Environmental Organisation. Environmental data Mira-T 2007. Emissions to the air: other pollutants [Kernset Milieudata Mira-T 2007. Emissie naar de lucht: alle andere polluenten]. See also: http://www. milieurapport.be/Upload/main/docs/Administrators/MIRA-T\%202007/Kernset \%20T2007_emissies_lucht_alle\%20andere\%20polluenten.xls; 2007 (in Dutch).

[32] Flemish Government. Department of agriculture and fishery. Agricultural report 2008 [Landbouwrapport 2008]. See also: http://lv.vlaanderen.be/ nlapps/docs/default.asp?id=1125; 2009 (in Dutch). 